\title{
A New Method to Assess the Light Pollution on Loggerhead Hatchlings from La Roche Percée Rookery, New Caledonia
}

\author{
Marion E Magnan ${ }^{1 *}$, Tyffen C Read ${ }^{2}$ and Richard Farman ${ }^{2}$ \\ ${ }^{1}$ University of Bourgogne, Dijon 21000, France \\ ${ }^{2}$ Laboratory of Marine Biology and Ecology, Aquarium des Lagons, New Caledonia \\ Submission: May 10, 2021; Published: June 28, 2021 \\ Corresponding author: Marion E Magnan, University of Bourgogne, Dijon 21000, France
}

\begin{abstract}
La Roche Percée, in New Caledonia, is the second most important nesting site for the south Pacific loggerheads turtle's population (Caretta caretta) after Eastern Australian rookeries. Light pollution is a worldwide issue on nesting beaches due to coastal development and can impact hatchlings sea turtles finding ability. This study focused on the assessment of light pollution on hatchlings at La Roche Percée. Measurements of hatchlings fans were performed on 82 emergences, only 7\% of them were considered as being disrupted and almost all of the disrupted emergences were located in the first beach section, during highly moon illumination. Dispersion fan angles from La Roche Percée were comparable to natural emergences observed at Mon Repos beach, Australia. La Roche Percée beach could be considered as not disturbed by light pollution despite the human population currently leaving close to the nesting site, however periodic light such as vehicle headlights, may impact hatchlings' orientation during their beach crawl.
\end{abstract}

Keywords: Orientation; Disorientation; Artificial light; Fan mapping

\section{Introduction}

The South Pacific loggerhead subpopulation (Caretta caretta) is listed as critically endangered (CR) on the IUCN red list [1]. New Caledonian rookeries are part of the Eastern Australian stock with more than $80 \%$ of its population nesting in Queensland rookeries (Australia) and a small part in New-Caledonia, mean of 44 females per year [2-5]. Since 1980, the South Pacific subpopulation has been in decline due to anthropogenic pressures [6]. Coastal development brought artificial lights from buildings, roads, shopping centres and others infrastructures increasing light pollution around nesting areas, affecting female frequentation and hatchlings sea finding ability $[7,8]$. Mon Repos Conservation Park is the main nesting site, in South Queensland, where hatchlings orientation is highly disrupted by light pollution [7].

After spending three to five days in the nest, hatchlings emerge as a group crawling out of the nest and scan the horizon across $180^{\circ}$ to identify environmental visual cues and be oriented toward the lowest brightness horizon [9-13]. The stereotypical behaviour of hatchling sea-finding is a positive orientation to light known as photo tropotaxis effect $[11,14]$. On developed beaches, the concentration of lights is more important and may increase the disorientation of hatchlings by non-detecting elevation and/ or shape cues. [15]. Disorientation is known to have negative consequences on hatchlings crawling performance, survival, and fitness $[13,16,17]$.

This study focuses on the main loggerhead turtle nesting beach in New Caledonia where the human population has grown to 120 residences by 2015, since the first Europeans settled in 1984 [3,5]. Light pollution is well studied in some part of the world (like Australia, Florida), but has never been studied in New Caledonia. The purpose of this paper is to examine a new method to assess light pollution that may disturb sea turtle's hatchling behaviour in this specific site and to discuss what actions could be put in place in order to mitigate the impact of light pollution at a larger scale.

\section{Materials and Methods}

The study took place during the nesting season at La Roche Percée $\left(21^{\circ} 36^{\prime} \mathrm{S}, 165^{\circ} 27^{\prime} \mathrm{E}\right)$ in New Caledonia between February 
$2^{\text {nd }}$ and March $5^{\text {th }}, 2$ 2017. La Roche Percée is an urbanized peninsula, located at $160 \mathrm{~km}$ north of Noumea, New Caledonia's capital (Figure 1). This peninsula forms La Roche Percée, a beach of $1.7 \mathrm{~km}$ long west-facing orientation, along it we found the main road. For our study, we numbered the streetlights along the road (from 1 to 45) that will help to determine the location of the nest. The beach is divided into 3 sections: from the streetlights 1 to 15 we found the first section, from lights 16 to 31 section 2 , and from lights 32 to 45 there is the third section of the beach.

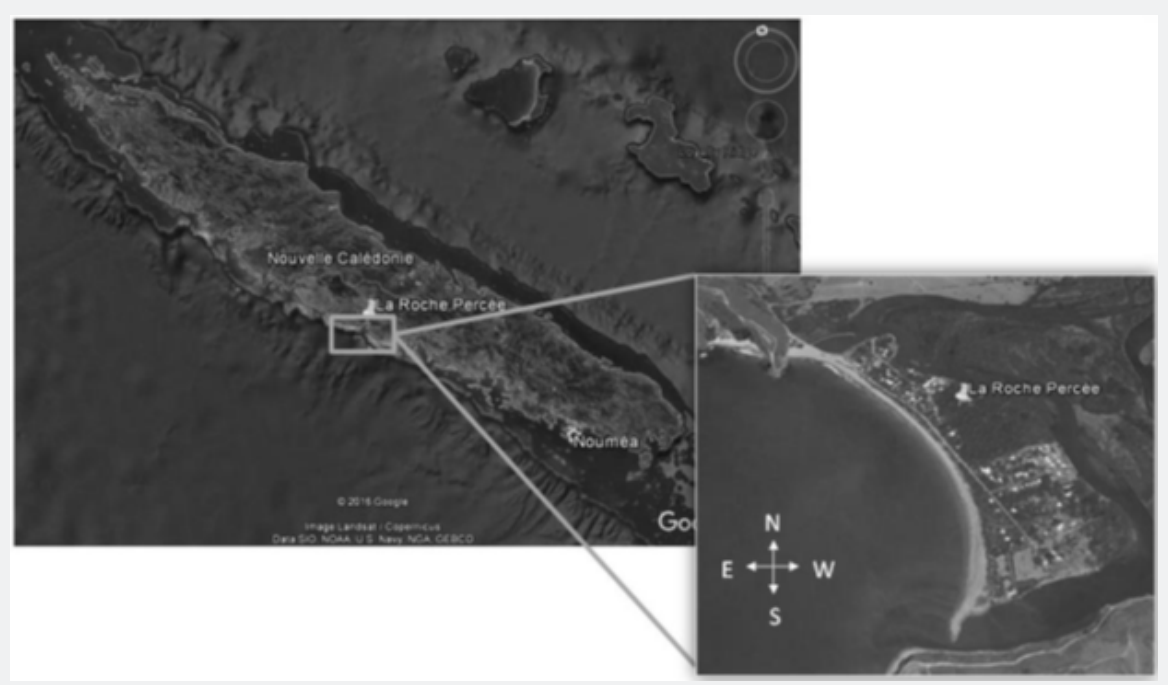

Figure 1: Maps of the New Caledonia with Noumea the capital and La Roche Percée $\left(21^{\circ} 36^{\prime} \mathrm{S}, 165^{\circ} 27^{\prime} \mathrm{E}\right)$ and an enlargement of the study place.

La Roche Percée is the second most important loggerhead nesting site for the east Pacific genetic stock after the Australian rookerie Mon Repos [2-4,6,18]. Waves, winds, and sea level changes caused coastal erosion, disrupting the nesting activity. A program of artificial re-nourishment, between 2010 and 2012, was realized to limit the loss of nesting habitat and to protect the housing development of the peninsula $[3,19,20]$. While street lighting is turned off during the nesting season, house lights, boats and vehicle headlights are additional source of light that could disturb sea turtle activities [21].

The emergence tracks of 82 nests were investigated with the fan mapping method, and our method differ from studies using the bearing compass method by calculate fans angle a posteriori $[7,15,22]$. This method is used indirectly to assess hatchlings sea finding behaviour under natural condition without human presence. Most nest emergences occurred at night after sunset, when the sand temperature drop and gives a signal to the hatchlings to dig through the surface avoiding potential predators and lethal daytime temperature [23-25]. Every morning of the study, a survey was conducted to record emergences activities from the previous night, after a fan mapping was performed hatchlings, tracks were wiped out with our feet to not record them twice.

The edges of the fan created by hatchlings crawled towards the ocean was marked by two skirting boards of 2 meters long (Figure 2). Stray tracks from individuals that did not fall within the main fan (maximum of five per nest) were not included within the fan boundaries fined by the skirting boards. Measurements performed were: "hatchling dispersion width" from the nest depression and at the end of the fan, the distance of the "most direct line to the ocean" from the nest. Pictures were taken for complementary information with the emergence beach localization and position (up, middle, or down of the beach). Particular weather events (rain, storm...) and full percentage of moon phase were coded. However, cloud cover variable was not considering due to the inability to determine emergence's time. Lunar predictions were defined with Quick-Phase Pro version 4 (http://www.quickphase. com).

Our method differs from previous studies, as the posterior fans' angle was calculated using basic trigonometric notion with a precision of $\pm 1^{\circ}$, by calculating the tangent of the angle. We calculate two angles, the spread angle (C) includes the largest part of the fan, without stray track, and the offset angle (X) corresponding to the fan angle midpoint and the most direct line to the ocean (Figure 3).These data were used to diagnose disorientation after Salmon and Witherington [15] who classified a fan as disoriented when hatchlings' sea orientation path was deviated from their route with an offset angle greater than $30^{\circ}$, and a spread angle greater than $90^{\circ}$.

A non-parametric multivariate analysis of variance (NPMANOVA) was used for each of the two dependent variables (spread and offset angle) to test if the independent variables affected spread or offset angle. The independent variables are the moon phase; the location of the nest is determined by the 
streetlight's numbers; the beach section is divided into 3 zones delimited by the same streetlights; and the emergence beach height is the location of the nest on the bottom, middle or top of the beach. To test which variables may impact the fan map, we performed a Kruskal-Wallis and the Nemenyi test (non-parametric multiple comparison post hoc). All statistical analysis were done using R software 3.2.5 and utilizing the "vegan" package to perform the NP-MANOVA, and the "PMCMR" package for the Nemenyi test.

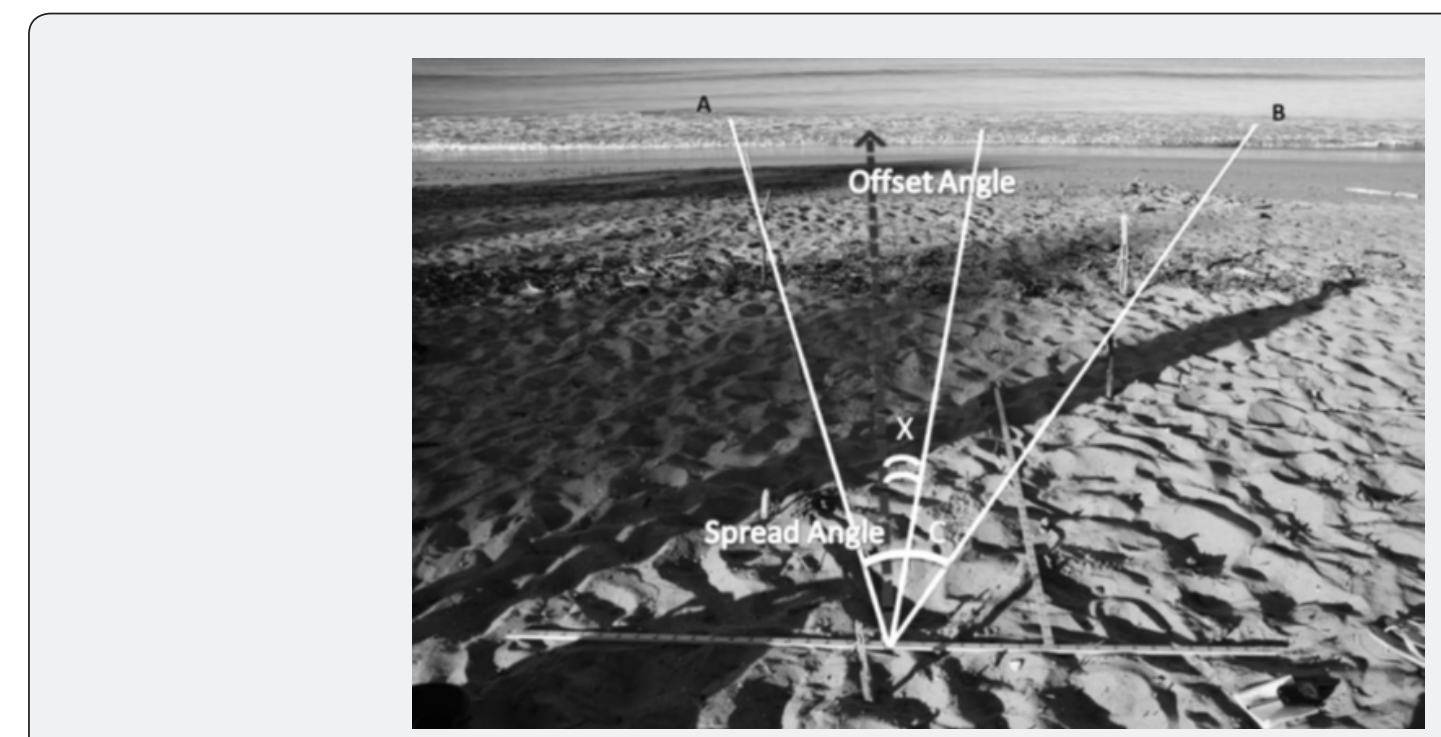

Figure 2: Emergence fan with measurements criteria. $A$ and $B$ are the outer edge of the fan, the black line is the most direct route to find the sea and the white line is the mean path took by the hatchling for the sea, $X$ is the offset angle between the most direct line to the sea and the mean way took by the hatchlings, $\mathrm{C}$ is the spread angle.

\section{Results}

The 82 emergences had an average spread of $28.75^{\circ}$ and offset angle of $7.36^{\circ}$ during the period of our study (Table 1). Of all tracks counted only $7 \%$ of fans recorded, corresponding to 6 fans, were considered as disrupted with an offset angle superior to $30^{\circ}$. In contrast, no spread angle higher than $90^{\circ}$ was observed but the spread angle on these six fans were comprised between 50-60.
The disruption of fan orientation occurred at $66 \%$ of time when the lunar illumination is higher than $50 \%$ of its capacity. Three of sea-finding disorientation occurred after the full moon (97.9\% of the moonlight), one occurred during the third quarter phase (52.6\% of the moonlight) and two others after the new moon. Five of six of these disorientations were recorded in the first beach section whereas one fan was presented at the last beach section when the moonlight is at $1.4 \%$.

Table 1: Analysis of combined fan spread angle and offset angle (mean \pm s.e.) for the three beach sections, disrupted, normal and total emergences.

\begin{tabular}{|c|c|c|c|c|c|}
\hline & & \multicolumn{2}{|c|}{$\begin{array}{c}\text { Spread angle } \\
\text { (degrees) }\end{array}$} \\
\hline & $\mathrm{n}$ & mean & s.e. & mean & s.e. \\
\hline Disrupted Emergences & 6 & 26.34 & 22.87 & 36.36 & 7.51 \\
\hline Normal Emergences & 76 & 28.75 & 13.59 & 2.74 & 1.73 \\
\hline Total Emergences & 82 & 28.57 & 14.27 & 7.36 & 9.61 \\
\hline
\end{tabular}

The non-parametric MANOVA test demonstrated there were significant multivariate effects on the orientation indices for 3 of the independent variables: the beach section $\left(\mathrm{F}=3.3102 ; \mathrm{M}^{2}=\right.$ 0.187505; $\mathrm{P}=0.044)$, moon phase $\left(\mathrm{F}=2.2745 ; \mathrm{M}^{2}=0.12884 ; \mathrm{P}=\right.$ $0.006)$ and nest location $\left(\mathrm{F}=1.6668 ; \mathrm{M}^{2}=0.094415 ; \mathrm{P}=0.023\right)$ (Table 2). The emergence beach height had no effect on hatchlings orientation ( $\left.\mathrm{F}=0.9338 ; \mathrm{M}^{2}=0.052895 ; \mathrm{P}=0.456\right)$. Lunar phase variable was tested independently with a Kruskall-Wallis and had a significant effect on the spread angle (KW: $\mathrm{df}=6 ; \mathrm{X}^{2}=16.318$;
$P=0.012)$. Following the Nemenyi test, significant differences were observed after the full moon and the third quarter phase $(\mathrm{P}=0.0075)$. The variable emergence beach height revealed a significant effect for the offset angle (KW: $\mathrm{df}=2 ; \mathrm{X}^{2}=6.3145 ; \mathrm{P}$ $=0.043)$. Contrary to the multivariate results, beach section (KW: $\mathrm{df}=2 ; \mathrm{P} \geq 0.056$ ) and nest location variables (KW: $\mathrm{df}=35 ; \mathrm{P} \geq$ 0.121 ) independently analysed did not significantly influence fans mapping. 
Table 2: Non-Parametric Multivariate analysis of variance (Non-parametric MANOVA) of the dependent variables spread angle and offset angle, and individual Kruskal-Wallis analysis of spread angle and offset angle according to the moon phase, beach position, nets location and emergence beach height effects.

\begin{tabular}{|c|c|c|c|c|c|}
\hline Test & Effect & Df & $\mathbf{F}$ & $\begin{array}{c}\text { Mean Square } \\
\left(M^{2}\right)\end{array}$ & p-value \\
\hline \multirow{4}{*}{$\begin{array}{l}\text { Non-Parametric Multivar- } \\
\text { iate Analysis of Variance } \\
\text { (NP-MANOVA) }\end{array}$} & Beach Section & 1 & 3.3102 & 0.187505 & 0.044 \\
\hline & Moon phase & 6 & 2.2745 & 0.12884 & 0.006 \\
\hline & Nest location & 34 & 1.6668 & 0.094415 & 0.023 \\
\hline & Emergence beach height & 2 & 0.9338 & 0.052895 & 0.456 \\
\hline Test & Effect & $\begin{array}{c}\text { Dependent } \\
\text { variable }\end{array}$ & Df & $\begin{array}{c}\text { Chi Squared } \\
\left(\mathrm{X}^{2}\right)\end{array}$ & p-value \\
\hline \multirow{8}{*}{ Kruskal-Wallis Test (KW) } & \multirow{2}{*}{ Beach Section } & Spread angle & 2 & 5.7511 & 0.056 \\
\hline & & Offset angle & 2 & 4.7414 & 0.093 \\
\hline & \multirow{2}{*}{ Moon Phase } & Spread angle & 6 & 16.318 & 0.012 \\
\hline & & Offset angle & 6 & 2.2085 & 0.9 \\
\hline & \multirow{2}{*}{ Nest location } & Spread angle & 35 & 42.573 & 0.177 \\
\hline & & Offset angle & 35 & 44.933 & 0.121 \\
\hline & \multirow{2}{*}{ Emergence beach height } & Spread angle & 2 & 0.14579 & 0.93 \\
\hline & & Offset angle & 2 & 6.3145 & 0.043 \\
\hline
\end{tabular}

\section{Discussion}

After emerging, hatchlings use visuals cues such as brightness source and horizon profile to crawl directly towards the ocean $[26,27]$. The eye acuity of hatchlings is known as cone of acceptance and allow them to integrate lights cues that influences detection, determination of brightness direction and the beach topography who moderates this cue information [22,28]. At La Roche Percée, only $7 \%$ of nests were disrupted and almost all of them were located in the first beach section when moon light was greater than $50 \%$. These disorientations may be explained by the beachcurved shape modifying light indices interpretation. Because of the beach shape, orientation and moon position, hatchlings integrate lights in the limit of their $180^{\circ}$ cone acceptance to be oriented towards the broad brightness and lowest horizon which may distracts fan orientation from the initial ocean line.

Nevertheless, cars regularly illuminated the first part of the beach and may influenced hatchling orientation. In this situation, hatchling orientation could be more affected because their responses depend on the difference in light brightness between natural and artificial stimuli on the horizon [29]. Unlike celestial point sources of light, artificial sources are not scattered in overhead sky and brightness illumination can be seen in only one direction [28]. Although a few stray tracks were recorded ( $20 \%$ of nests recorded) lost hatchlings had difficulties finding their way towards the ocean and could be due to an external factor stimulating them away from the main emergence. During our study, 5 hatchlings were found on the middle of the main road showing an important disruption in their orientation and may suggest more hatchlings could be lost and crawled towards the road. All the direction changes and irregular movements affect their fitness as well as their survival due to exhaustion, dehydration, and increased predation risks [28].

Comparison of fan spread, and offset angles recorded on different beaches in the literature showed differences on the fan orientation. On the eight fans research projects using bearing compass method $[7,15,22,30]$, six were conducted in the Queensland region of Eastern Australia (Loggerhead and Flatback turtles), one in the Western Australia coast (Green and Flatback turtles) and one in Florida (Loggerhead turtles) (Table 3). Between 2012-2014 at the Eastern Australia coast, spread and offset angles were less widespread and less disrupted $\left(126.3^{\circ}\right.$ in 2012 and $91.2^{\circ}$ in 2013 for the spread angle) [30]. Hatchlings spread angle at La Roche Percée was not really extent $\left(28.57^{\circ}\right.$ ) equivalent to a normal sea-finding dispersion $\left(24^{\circ}\right)$ recorded in Queensland (2010) [7]. Salmon and Witherington [15] classified hatchlings orientation as disrupted when spread angle was higher than $90^{\circ}$ and/or offset angle higher than $30^{\circ}$ on beaches where artificial light was visible. The comparison of the nine studies where fans recorded (our study and literature), only three were considered as disrupted sea-finding behaviour for the orientation indices (Table 3).

Results from this study indicates that La Roche Percée is a relatively light pollution free beach with fan dispersions comparable to natural emergences at Mon Repos beach [7]. This study provides the first data on hatchling orientation in New Caledonia and reveals an absence of light pollution disrupting hatchlings sea-finding. However periodic light troubles, such as vehicle headlights, may potentially disrupt Loggerhead Sea 
finding behaviour. Reductions of these sources during the nesting season are strongly recommended. We recommend road users to minimize the use of vehicle headlight during the sea turtle nesting season to limit light pollution on the beach and hatchling sea turtle lost on the road. Regulated access to the beach at specific crossing points, with awareness posters, should give all information the public needs to avoid disrupting turtles. This research project presents is limited in the size of the data set, a new method used, and time of the season data was collected in February providing a partial overview of the seasonal hatchling behaviour. Future studies should be carried out over an entire hatchling season and across at least 2 years, with the common method of the bearing compass, to compare the evolution of light pollution on hatchling sea finding behaviour.

Table 3: Comparison of hatchling fan orientation for La Roche Percée (mean \pm s.e.) with four other studies at different beaches (eight fan orientation). $\mathrm{N}$ is for a normal sea-finding behaviour and $\mathrm{D}$ or in bold type for a disrupted sea-finding behaviour.

\begin{tabular}{|c|c|c|c|c|c|c|c|}
\hline \multirow[t]{2}{*}{ Study } & \multirow[t]{2}{*}{ Year } & \multirow[t]{2}{*}{$\mathbf{n}$} & \multicolumn{2}{|c|}{$\begin{array}{l}\text { Spread angle } \\
\text { (degrees) }\end{array}$} & \multicolumn{2}{|c|}{$\begin{array}{l}\text { Offset angle } \\
\text { (degrees) }\end{array}$} & \multirow[t]{2}{*}{ Localization Study } \\
\hline & & & mean & s.e. & mean & s.e. & \\
\hline $\begin{array}{l}\text { Salmon and Witherington (1995) } \\
\text { Loggerhead turtles }\end{array}$ & 1995 & 940 & 34 & 10 & 3 & 4 & $\begin{array}{c}\text { Florida } \\
\text { (River County) }\end{array}$ \\
\hline $\begin{array}{l}\text { Pendoley (2005) Green and Flatback } \\
\text { Turtles }\end{array}$ & $\begin{array}{c}1996- \\
2003\end{array}$ & 384 & 41 & 21 & 15 & 26 & $\begin{array}{l}\text { Barrow Lowendal Montebello } \\
\text { Islands (Western Australia) }\end{array}$ \\
\hline \multirow{5}{*}{$\begin{array}{c}\text { Karwowska et al, (2014) Flatback } \\
\text { Turtles }\end{array}$} & \multirow{2}{*}{2012} & 68 & 55.1 & 4.5 & 18.3 & 1.9 & Peak (Eastern Australia) \\
\hline & & 19 & 126.3 & 18.5 & 66.4 & 15.1 & Curtis (Eastern Australia) \\
\hline & \multirow{2}{*}{2013} & 64 & 54.7 & 3.3 & 19.4 & 2.1 & Peak (Eastern Australia) \\
\hline & & 48 & 91.2 & 11.2 & 46.3 & 7.8 & Curtis (Eastern Australia) \\
\hline & 2014 & 23 & 53 & 10.2 & 23 & 7.9 & Curtis (Eastern Australia) \\
\hline \multirow{2}{*}{$\begin{array}{c}\text { Berry et al, (2013) Loggerhead } \\
\text { Turtles }\end{array}$} & \multirow[b]{2}{*}{2010} & $175(\mathrm{~N})$ & 24 & 1 & 5 & 1 & Mon Repos Beach, \\
\hline & & 12 (D) & 163 & 31 & 40 & 20 & $\begin{array}{c}\text { Kelly's Beach } \\
\text { (Eastern Australia) }\end{array}$ \\
\hline Our Study Loggerhead Turtles & 2017 & 82 & 28.57 & 14.27 & 7.36 & 9.61 & New-Caledonia (La Roche Percée) \\
\hline
\end{tabular}

\section{Conclusion}

La Roche Percée is the second most important loggerhead nesting site of the South Pacific, and this study is the first one to quantify sea turtle hatchling fan characteristics in New Caledonia. La Roche Percée is a non-light polluted beach as indicated by relatively few disrupted hatchling fans. Nonetheless, the beach is periodically illuminated by vehicles headlights which may impact hatchlings orientation, but it is impossible to quantify the degree of this disturbance and at this point only recommendations can be made. Our study using a new method of fan mapping seem to show this nesting site is non disrupted by light pollution, a comparison of our results by using a bearing compass in a near future could validate the new mapping method. These preliminaries data could serve as reference for future studies in New-Caledonia. We recommend that guidelines should be established in order to limit lighting around nesting beaches of New Caledonia and sea turtles nesting site should be considered when new constructions are allowed. Continuing orientation and light studies on a long-term basis for this nesting beach and for the other important sea turtle nesting beaches of New Caledonia should also be done, as the number of inhabitants is growing rapidly.

\section{References}

1. IUCN (2015) The IUCN Red List of Threatened Species : Caretta caretta (South Pacific subpopulation), Loggerhead Turtle.
2. Boyle MC, FitzSimmons NN, Limpus CJ, Velez-Zuaco X, Waycott M (2009) Evidence for transoceanic migrations by loggerhead sea turtles in the southern Pacific Ocean. Proceedings of the Royal Society B: Biological Sciences 327029: 1-7.

3. Fourniere K, Jacob T, Lafage D (2015) Bilan de huit années de suivi des tortues grosses têtes (Caretta caretta) par l'association Bwärä Tortues Marines et perspectives (sites de la Roche Percée et de la Baie des Tortues).

4. Limpus C J (2008) A biological review of Australian marine turtles. 1. Loggerhead turtle, Caretta caretta (Linnaeus). Environmental Protection Agency.

5. Limpus C J, Boyle M, Sunderland T (2006) New Caledonian Loggerhead Turtle Population Assessment: 2005 Pilot Study. In: Second Edition Volume II North Pacific Loggerhead Sea Turtles, Pp. 77-93.

6. Limpus C J, Limpus D J (2003) Loggerhead turtles in the equatorial and southern Pacific Ocean: a species in decline. In: AB Bolten, BE Witherington (Eds). Loggerhead Sea Turtles, Smithsonian Institution Press, Washington, DC. Pp. 199-209.

7. Berry M, Booth DT, Limpus CJ (2013) Artificial lighting and disrupted sea-finding behaviour in hatchling loggerhead turtles (Caretta caretta) on the Woongarra coast, south-east Queensland, Australia. Australian Journal of Zoology 61(2): 137-145.

8. Navara KJ, Nelson RJ (2007) The dark side of light at night: physiological, epidemiological, and ecological consequences. J Pineal Res 43(3): 215-224.

9. Bertolotti L, Salmon M (2005) Do embedded roadway lights protect sea turtles? Environ Manage 36(5): 702-710. 
10. Daniel RS, Smith KU (1947) The sea-approach behavior of the neonate loggerhead turtle (Caretta caretta). J Comp Physiol Psychol 40(6): 413420 .

11. Ecological Associates (2002) Coastal roadway lighting manual. A handbook of practical guidelines for managing street lighting to minimize impacts to sea turtles.

12. Lohmann KJ, Lohmann CM (2003) Orientation mechanisms of hatchlings loggerheads. In: $\mathrm{AB}$ Bolten, $\mathrm{BE}$ Witherington (Eds). Loggerhead Sea Turtles, Smithsonian Institution Press, Washington, DC. Pp. 199-209.

13. Salmon M (2003) Artificial lighting and sea turtles. The Biologist 50: 163-168.

14. Mrosovsky N, Kingsmill SM (1985) How Turtles Find the Sea. Zeitschrift fur Tierpsychologie 67: 237-256.

15. Salmon M, Witherington BE (1995) Artificial Lighting and Seafinding by Loggerhead Hatchlings : Evidence for Lunar Modulation. American Society of Ichhyologists and Herpetologists (ASIH) 4: 931-938.

16. Fuentes MM, Gredzens C, Bateman BL, Boettcher R, Ceriani SA, et al. (2016) Conservation hotspots for marine turtle nesting in the United States based on coastal development. Ecol Appl 26(8): 2706-2717.

17. Magyar T (2008) The impact of artificial lights and anthropogenic noise on Loggerheads (Caretta caretta) and Green Turtles (Chelonia mydas), assessed at index nesting beaches in Turkey and Mexico. Universität Bonn.

18. Auzon J (2007) Marine turtles of New Caledonia. In: CE Payri, B Richier de Forges (Eds.) ( $2^{\text {nd }}$ edn). Nouméa: Centre IRD de Nouméa.

19. Brock KA, Reece JS, Ehrhart LM (2009) The effects of artificial beach nourishment on marine turtles: Differences between loggerhead and green turtles. Restoration Ecology 17(2): 297-307.

20. Peterson CH, Bishop MJ (2005) Assessing the Environmental Impacts of Beach Nourishment. BioScience 55(10): 887-896.
21. Witherington BE (1992) Behavioral Responses of Nesting Sea Turtles to Artificial Lighting. Herpetologica 48(1); 31-39.

22. Pendoley KL (2005) Sea turtles and the environmental management of industrial activities in northwest Western Australia. Murdoch University.

23. Glen F, Broderick AC, Godley BJ, Hays GC (2005) Patterns in the emergence of green (Chelonia mydas) and loggerhead (Caretta caretta) turtle hatchlings from their nests. Marine Biology 146: 1039-1049.

24. Limpus CJ (1985) A study of the loggerhead sea turtle, Caretta caretta in eastern Australia. PhD Thesis, The University of Queensland, Brisbane.

25. Miller JD (1996) Reproduction in Sea Turtles. In: PL Lutz, JA Musick (Eds). The Biology of Sea Turtles, Pp. 51-80.

26. Limpus CJ, Kamrowski RL (2013) Ocean-finding in marine turtles: the importance of low horizon elevation as an orientation cue. Behaviour 150: 863-893.

27. Lohmann KJ, Witherington BE, Lohmann CM, Salmon M (1997) Orientation, Navigation, and Natal Beach Homing in Sea Turtles. In: (1 $1^{\text {st }}$ edn). The Biology of Sea Turtles, Pp. 107-131.

28. Witherington BE, Martin RE (1996) Understanding, Assessing, and Resolving Light-Pollution Problems on Sea Turtle Nesting Beaches. Chelonian Conservation and Biology.

29. Tuxbury SM, Salmon M (2005) Competitive interactions between artificial lighting and natural cues during seafinding by hatchling marine turtles. Biological Conservation 121(2): 311-316.

30. Witherington BE (1995) Observations of hatchling loggerhead turtles during the forts few days of the lost year(s). Proceedings of the 12th Annual Workshop on Sea Turtle Biology and Conservation 154-156.

\section{Your next submission with Juniper Publishers} will reach you the below assets

- Quality Editorial service

- Swift Peer Review

- Reprints availability

- E-prints Service

- Manuscript Podcast for convenient understanding

- Global attainment for your research

- Manuscript accessibility in different formats

( Pdf, E-pub, Full Text, Audio)

- Unceasing customer service

Track the below URL for one-step submission https://juniperpublishers.com/online-submission.php 